\title{
Investigations on automatically measured feed intake amount in dairy cows during the oestrus period
}

\author{
K. Halli ${ }^{1}$, C. Koch ${ }^{2}$, F.-J. Romberg ${ }^{3}$, and S. Hoy ${ }^{1}$ \\ ${ }^{1}$ Institute of Animal Breeding and Genetics, Justus Liebig University Giessen, Giessen, Germany \\ ${ }^{2}$ Educational and Research Centre for Animal Husbandry, Hofgut Neumühle, \\ Münchweiler an der Alsenz, Germany \\ ${ }^{3}$ Dienstleistungszentrum Ländlicher Raum Westpfalz (DLR), Münchweiler an der Alsenz, Germany \\ Correspondence to: K. Halli (kathrin.halli@agrar.uni-giessen.de)
}

Received: 14 April 2014 - Accepted: 8 December 2014 - Published: 9 March 2015

\begin{abstract}
The aim of this study was to determine whether feed intake amount and feed intake behaviour could be related to oestrus in dairy cows. Furthermore, we investigated whether oestrus had an effect on daily milk yield. A total of 138 oestrus cycles, leading to conception of 100 cows, were analysed. The parameters "daily fresh matter intake amount (kg)", "daily number of visits to the feeding trough" and "time spent feeding per day (min)" were electronically measured and recorded. For a sub-quantity of all animals, daily milk yield (kg) was recorded continuously and stored in the herd management software. Special attention was given to the day of oestrus, which was defined as the day of successful insemination. All remaining days of the oestrus cycle were considered as the reference period. Among all animals and cycles, fresh matter intake amount per day, number of visits per day, and time spent feeding per day were reduced by $10.3,9.1$ and $20.8 \%$, respectively, on the day of oestrus. Fresh matter intake was significantly lower in primiparous cows than in multiparous cows. However, number of visits to the trough and time spent feeding per day were significantly higher in primiparous cows compared to multiparous cows. Day of oestrus did not have a significant effect on daily milk yield, as this parameter was characterized by high variation among all days of the oestrus cycle. In conclusion, if an RIC system is used, monitoring of feeding behaviour appears to be a potential auxiliary aid in oestrus detection.
\end{abstract}

\section{Introduction}

At $35 \%$, fertility management is the factor exerting the highest influence on fertility (Bostedt, 2006). One very important part of fertility management is heat detection. When compared to older cows, heifers show reduced oestrus intensity (Gwazdauskas et al., 1983). This can also be observed in high-yielding dairy cows, accompanied by a decreased length of oestrus (Lopez et al., 2004). Therefore, visual heat detection becomes more problematic and is also associated with a high expenditure of time. To support visual heat detection, more complex and computer-based methods have been developed. Pedometers, used for measurements of daily physical activity in dairy cows, have proven that movement activity is about 4 times higher during oestrus when housed in free stalls, and about 2.75 times higher in com- fort stalls compared to the other stages of the oestrus cycle (Kiddy, 1977). Similar results were determined by Schofield et al. (1991), who found increased activity levels in cows on the day of oestrus by a mean factor of 2.3. Furthermore, rumination time is significantly reduced during oestrus. Using a microphone-based sensor system for continuous recording of rumination time, an average decrease of $17 \%\left(74 \mathrm{~min} \mathrm{~d}^{-1}\right)$ was determined on the day of oestrus compared to the reference period (mean of 3 days before and 3 days after oestrus) (Reith and Hoy, 2012).

The aim of the study was to determine whether oestrus in dairy cows also had an effect on feed intake amount, feed intake behaviour and milk yield. Furthermore, the effect of parity on investigated feed intake parameters was analysed. Additionally, the investigation should answer the question of whether the decrease in daily rumination time during oestrus 
described by Reith and Hoy (2012) is caused by the decrease in feed intake, as expected.

\section{Materials and methods}

\subsection{Housing, animals and diet}

The study was conducted at the Educational and Research Centre for Animal Husbandry Hofgut Neumühle, located in Münchweiler an der Alsenz in Rhineland-Palatinate, Germany. A total of 100 lactating Holstein-Friesian dairy cows born during the period between 2004 and 2010 were analysed. The number of lactations ranged from 1 to 6 , with an average of 2.46 lactations. The data collection included 138 oestrus cycles leading to conception ( 32 cycles of the first lactation and 106 cycles of higher lactations).

The investigation was performed in a free-stall barn consisting of two different sectors - the sector of production and the experimental sector - in which all cows of this study were housed. The experimental sector was a separate part of the stable with 60 cubicles and 30 feeding troughs. Generally closed with a gate, the troughs are equipped with an RIC (Roughage Intake Control) automatic weighing system, manufactured by Insentec B.V. (Marknesse, the Netherlands). The system identifies each animal by scanning the individual transponder, installed within the cow's collar, via light barriers. Once identified, the gate permits access to the feeding trough and the scale automatically records the amount of feed consumed at each visit. Therefore, all visits of each cow to the trough with feed intake and the duration of each visit were recorded by the system. The milking parlour used was a combination of a herringbone parlour offering space for 8 cows and a side-by-side parlour for 10 cows, manufactured by GEA Farm Technologies (located in Bönen, Germany).

Cows were fed a total mixed ration (TMR) ad libitum containing $46.6 \%$ dry matter. The TMR was composed for dairy cows of a mean live weight of $650 \mathrm{~kg}$, a mean feed intake of $21.7 \mathrm{~kg}$ dry matter per day and a mean milk production of $34 \mathrm{~kg}$ per day. For detailed composition and the ingredients of the experimental ration, see Table 1.

Cows were milked two times a day at 05:00 and at 15:30. Feeding troughs were filled once a day at around 06:30 with around $80-85 \mathrm{~kg}$ of feed after the leftover feed of the previous day was removed. During milking in the morning, troughs were closed for cleaning for 20 to $30 \mathrm{~min}$. Fresh water was freely available at any time of the day. Date of birth, insemination, calving, length of gestation, number of lactations and daily milk yield were stored and provided by the herd management program DairyPlan C21 (GEA Farm Technologies). The day of oestrus (day 0) was defined as the day of successful insemination, detected either by visual observation and/or physical activity measurement.
Table 1. Composition and ingredients of the TMR.

\begin{tabular}{lr}
\hline Composition & \% of dry matter \\
\hline Pressed beet pulp silage & 18.0 \\
Grass silage (first cut 2012) & 21.5 \\
Straw and hay & 3.2 \\
Maize silage & 21.4 \\
Grain maize & 10.1 \\
Barley & 8.1 \\
Extracted soybean meal & 4.0 \\
Extracted rapeseed meal & 12.2 \\
Cattle salt & 0.3 \\
Urea & 0.5 \\
Feed lime & 0.2 \\
Mineral feed & 0.5 \\
\hline Ingredients & \\
\hline Metabolizable energy, MJ ME d & \\
Net energy lactation, MJ NEL & 11.1 \\
Crude protein, g & 6.8 \\
Crude fibre, g & 159.3 \\
Usable crude protein (nXP), g & 173.0 \\
Ruminal nitrogen balance (RNB), g & 155.1 \\
Calcium, g & 0.9 \\
Phosphorus, g & 5.8 \\
Magnesium, g & 4.5 \\
Sodium, g & 2.5 \\
\hline
\end{tabular}

\subsection{Parameters and methods}

Data of 262 oestrus cycles were collected in the time period from 17 May 2010 to 3 July 2012 and based on a number of 146 animals. Due to missing data for 1 or more days of the oestrus cycle in 124 recorded cycles, the data set was reduced to 138 cycles (100 animals). The three parameters "daily feed intake amount (kg)", "daily number of visits to the feeding trough" and "time spend feeding per day ( $\mathrm{min}$ )" ( $n=2898$ each) were analysed. Only those oestrus cycles for which insemination was successful and pregnancy was proven were included in the statistical analysis. Special attention was given to the day of oestrus (day 0). All remaining days of the oestrus cycle were considered as the reference period. For 37 cows, data were recorded for two lactations. Due to very short intervals between calving and successful new insemination (days open) for one cow, data of three lactations were collected. The data set, automatically recorded at each visit to the trough, consisted of the following information: transponder ID, collar number, trough number (130 ), time of the cow's entrance and exit (HH:MM:SS), duration of the stay in seconds (s), weight of the trough at the time of entrance and the weight at the time of exit $(\mathrm{kg})$, feeding group, and amount of fresh matter intake $(\mathrm{kg})$. Duration of each stay in seconds, amount of fresh matter intake per visit and milk yield per milking were summarized to one value per day each. With regards to the dry matter content 
Table 2. Means of investigated parameters and differences between the day of oestrus (day 0) and the reference period (Rp) and between primiparous (Pp) and multiparous (Mp) cows.

\begin{tabular}{|c|c|c|c|c|c|c|c|c|c|}
\hline & $\begin{array}{l}N, \\
\text { days }\end{array}$ & $\begin{array}{l}\text { FMI, } \\
\operatorname{kg~d}^{-1}\end{array}$ & $\mathrm{SE}$ & $\begin{array}{l}\text { DMI, } \\
\mathrm{kg} \mathrm{d}^{-1}\end{array}$ & $\mathrm{SE}$ & $\begin{array}{l}\text { Time spent } \\
\text { feeding, } \min ^{-1}\end{array}$ & SE & $\begin{array}{l}\text { Visits to the } \\
\text { trough, } \mathrm{nd}^{-1}\end{array}$ & SE \\
\hline Means & 2898 & 42.5 & 0.4 & 19.8 & 0.2 & 190.8 & 3.2 & 48.5 & 1.2 \\
\hline \multicolumn{10}{|l|}{ Oestrus } \\
\hline Day 0 & 138 & $40.2^{\mathrm{a}}$ & 0.8 & $18.7^{\mathrm{a}}$ & 0.4 & $168.7^{\mathrm{a}}$ & 6.2 & 46.2 & 2.4 \\
\hline $\mathrm{Rp}$ & 2760 & $44.8^{\mathrm{b}}$ & 0.2 & $20.9^{b}$ & 0.1 & $212.9^{b}$ & 1.4 & 50.8 & 0.5 \\
\hline Diff. & & 4.6 & & 2.2 & & 44.2 & & 4.6 & \\
\hline Diff., \% & & 10.3 & & 10.5 & & 20.8 & & 9.1 & \\
\hline \multicolumn{10}{|l|}{ Parity } \\
\hline Pp cows & 672 & $39.2^{\mathrm{a}}$ & 0.7 & $18.3^{\mathrm{a}}$ & 0.3 & $205.3^{\mathrm{a}}$ & 5.6 & $53.3^{\mathrm{a}}$ & 2.2 \\
\hline Mp cows & 2226 & $45.8^{\mathrm{b}}$ & 0.4 & $21.4^{\mathrm{b}}$ & 0.2 & $176.3^{b}$ & 3.1 & $43.7^{\mathrm{b}}$ & 1.2 \\
\hline Diff. & & 6.6 & & 3.1 & & 29.0 & & 9.6 & \\
\hline Diff., \% & & 14.4 & & 14.5 & & 14.1 & & 18.0 & \\
\hline
\end{tabular}

Rp: reference period; Pp: primiparous cows; Mp: multiparous cows; FMI: fresh matter intake; DMI: dry matter intake; SE: standard error.

Means with different superscripts within a column differ significantly $(P<0.001)$

of the TMR $(46.6 \%)$, fresh matter $(\mathrm{kg})$ was converted into dry matter $(\mathrm{kg})$. To analyse the effect of lactation number on the three investigated parameters, lactation numbers were split into two groups: first lactation $(n=32)$, with a data set of 672 days, and higher lactation numbers ( 2 to 6$)(n=106)$, with a data set of 2226 days. For some cows the data set for "daily milk yield (kg)" was not recorded at all or was not complete. Therefore, the number of recorded values was much lower (525 days, 25 cycles) and based on 24 animals.

\subsection{Statistical analysis}

The statistical analysis of all data was performed with the program package SPSS 20.0 (SPSS Inc., Chicago, IL, USA). Using descriptive statistics, normal distributions were assessed for all variables by means of the KolmogorovSmirnov test. Using analysis of variance (GLM), "daily fresh matter intake amount (kg)", "daily dry matter intake amount $(\mathrm{kg})$ ", "daily number of visits to the feeding trough" and "time spent feeding per day (min)" were analysed for influences of oestrus and parity. Therefore, the day of oestrus (day 0) was compared to the reference period. To determine the effect of parity, primiparous cows were analysed for differences with multiparous cows. The following factors were included in the fixed model (GLM):

$$
\begin{aligned}
Y_{i j} & =\mu+\text { day of oestrus }_{i}+\text { parity }_{j} \\
& +\left(\text { day of oestrus }_{i} \times \text { parity }_{j}\right)+e_{i j},
\end{aligned}
$$

where $Y_{i j}$ is one of the variables "amount of fresh matter intake $\left(\mathrm{kg} \mathrm{d}^{-1}\right)$ ", "amount of dry matter intake $\left(\mathrm{kg} \mathrm{d}^{-1}\right)$ ", "number of visits to the trough per day" or "length of stay at the trough $\left(\operatorname{mind}^{-1}\right) " ; \mu$ is the mean; day of oestrus ${ }_{i}$ is the fixed effect of days of oestrus cycle ( $i$ being day of oestrus, reference period (mean of all remaining 20 days of the oestrus cycle)); parity ${ }_{j}$ is fixed effect of parity ( $j$ being lactation number 1 , lactation $\geq 2)$; $\left(\right.$ day of oestrus ${ }_{i} \times$ parity $_{j}$ ) is interaction between day of oestrus and parity; and $e_{i j}$ is the random residual error.

The parameter "daily milk yield" was analysed for significant differences between all days of the oestrus cycle by means of the Student-Newman-Keuls test. Differences among means with $P<0.05$ were accepted as representing significant differences.

\section{Results}

\subsection{Amount of fresh/dry matter intake $\left(\mathrm{kg} \mathrm{d}^{-1}\right)$}

On average, cows consumed $42.5 \mathrm{~kg} \mathrm{~d}^{-1}$ of fresh matter $(n=2898)$. At a dry matter content of $46.6 \%$, this value represents a dry matter intake of $19.8 \mathrm{~kg} \mathrm{~d}^{-1}$ on average. Feed intake amount was significantly affected by oestrus $(P \leq 0.001)$. Compared to the reference period $(44.8 \mathrm{~kg}$ fresh matter or $20.9 \mathrm{~kg}$ dry matter per day), the amount of fresh matter intake was about $10.3 \%$ lower on day $0(40.2 \mathrm{~kg}$ fresh matter or $18.7 \mathrm{~kg}$ dry matter per day) (Table 2). Parity also significantly affected the amount of fresh matter intake $(P \leq 0.001)$. Cows of first lactation consumed an average of $39.2 \mathrm{~kg}$ fresh matter ( $18.3 \mathrm{~kg}$ dry matter) per day. When compared to cows of higher parity $(45.8 \mathrm{~kg}$ fresh matter or $21.4 \mathrm{~kg}$ dry matter per day), cows of first lactation consumed $14.4 \%$ less. Also, the effect of oestrus concerning feed intake was more pronounced in multiparous cows (13.2\%) than in primiparous cows $(6.9 \%)$ (Table 3$)$. 
Table 3. Means of investigated parameters during, and differences between, the reference period and the day of oestrus (day 0) for primiparous and multiparous cows.

\begin{tabular}{|c|c|c|c|c|c|c|c|c|c|c|c|c|c|c|c|c|c|}
\hline & & $\begin{array}{l}\text { FMI }^{*} \\
\mathrm{~kg} \mathrm{~d}^{-1}\end{array}$ & SE & $\begin{array}{l}\text { Diff., } \\
\mathrm{kg}\end{array}$ & $\begin{array}{l}\text { Diff., } \\
\%\end{array}$ & $\begin{array}{l}\mathrm{DMI}^{*} \\
\mathrm{~kg} \mathrm{~d}^{-1}\end{array}$ & SE & $\begin{array}{l}\text { Diff., } \\
\text { kg }\end{array}$ & $\begin{array}{l}\text { Diff., } \\
\%\end{array}$ & $\begin{array}{l}\text { Time spent } \\
\text { feeding, } \\
{\min \mathrm{d}^{-1}}^{-1}\end{array}$ & $\mathrm{SE}$ & $\begin{array}{l}\text { Diff., } \\
\text { min }\end{array}$ & $\begin{array}{l}\text { Diff., } \\
\%\end{array}$ & $\begin{array}{l}\text { Visits to } \\
\text { the trough, } \\
\mathrm{nd}^{-1}\end{array}$ & SE & $\begin{array}{l}\text { Diff., } \\
n\end{array}$ & $\begin{array}{l}\text { Diff., } \\
\%\end{array}$ \\
\hline Parity & Oestrus & & & & & & & & & & & & & & & & \\
\hline \multirow{2}{*}{ Pp cows } & Day 0 & 37.8 & 1.3 & \multirow{2}{*}{2.8} & \multirow{2}{*}{6.9} & 17.6 & 0.6 & \multirow{2}{*}{1.3} & \multirow{2}{*}{6.9} & 185.8 & 10.9 & \multirow{2}{*}{39.1} & \multirow{2}{*}{17.4} & 51.6 & 4.2 & \multirow{2}{*}{3.4} & \multirow{2}{*}{6.2} \\
\hline & $\mathrm{Rp}$ & 40.6 & 0.3 & & & 18.9 & 0.1 & & & 224.9 & 2.4 & & & 55.0 & 0.9 & & \\
\hline \multirow{2}{*}{ Mp cows } & Day 0 & 42.6 & 0.7 & \multirow{2}{*}{6.5} & \multirow{2}{*}{13.2} & 19.8 & 0.3 & \multirow{2}{*}{3.1} & \multirow{2}{*}{13.5} & 151.6 & 6.0 & \multirow{2}{*}{49.4} & \multirow{2}{*}{24.6} & 40.8 & 2.3 & \multirow{2}{*}{5.8} & \multirow{2}{*}{12.4} \\
\hline & $\mathrm{Rp}$ & 49.1 & 0.2 & & & 22.9 & 0.1 & & & 201.0 & 1.3 & & & 46.6 & 0.5 & & \\
\hline
\end{tabular}

Rp: reference period; Pp: primiparous cows; Mp: multiparous cows; FMI: fresh matter intake; DMI: dry matter intake; SE: standard error.

$*(P<0.05)$.

\subsection{Number of visits to the trough per day}

Including 2898 values a mean number of 48.5 visits to the feeding trough per cow and day was evaluated. On average, cows visited the feeding trough 46.2 times on the day of oestrus and 50.8 times during the reference period $(9.1 \%$ less) (Table 2). However, this difference was not significant. Parity significantly affected this parameter $(P \leq 0.001)$. Primiparous cows visited the trough on average 53.3 times a day, while an average of 43.7 visits per day was determined for multiparous cows. The effect of oestrus was more strongly pronounced in multiparous cows $(12.4 \%)$ than in primiparous cows $(6.2 \%)$ (Table 3$)$.

\subsection{Length of stay at the trough $\left(\mathrm{min}^{-1}\right)$}

On average, cows spent 190.8 min $^{-1}$ feeding $(n=2898)$. Comparing the day of oestrus with the reference period, a decrease of $20.8 \%$ was found (168.7 vs. $212.9 \mathrm{~min} \mathrm{~d}^{-1}$, respectively). This difference of $44.2 \mathrm{~min}^{-1}$ was significant $(P \leq$ 0.001) (Table 2). Analysing this parameter with regard to parity, a difference of $14.1 \%$ was calculated between primiparous and multiparous cows $(P \leq 0.001)$. Presenting an average duration of stay at the feeding trough of $205.3 \mathrm{~min} \mathrm{~d}^{-1}$, primiparous cows spent more time feeding than multiparous cows (176.3 $\mathrm{min}^{-1}$ ) (Table 2). The effect of oestrus again was more strongly pronounced in multiparous cows (24.6\%) compared to primiparous cows (17.4\%) (Table 3).

\subsection{Daily milk yield $(\mathrm{kg})$}

Average daily milk yield of cows was $43.8 \mathrm{~kg} \mathrm{~d}^{-1}(n=525$ days). Due to high variation among all 21 days of the oestrus cycle, milk yield was not significantly affected by "day of oestrus" (Fig. 1). Means of daily milk yield ranged from $41.0 \mathrm{~kg} 8$ days prior to oestrus to $46.1 \mathrm{~kg} 5$ days after oestrus. An average milk yield of $44.0 \mathrm{~kg}$ was determined for day 0 . Milk yield was slightly reduced 1 day after oestrus by $1.8 \mathrm{~kg}$ (4.1\%), followed by an increase of $3.3 \mathrm{~kg}(7.8 \%)$ on day 2 after oestrus.

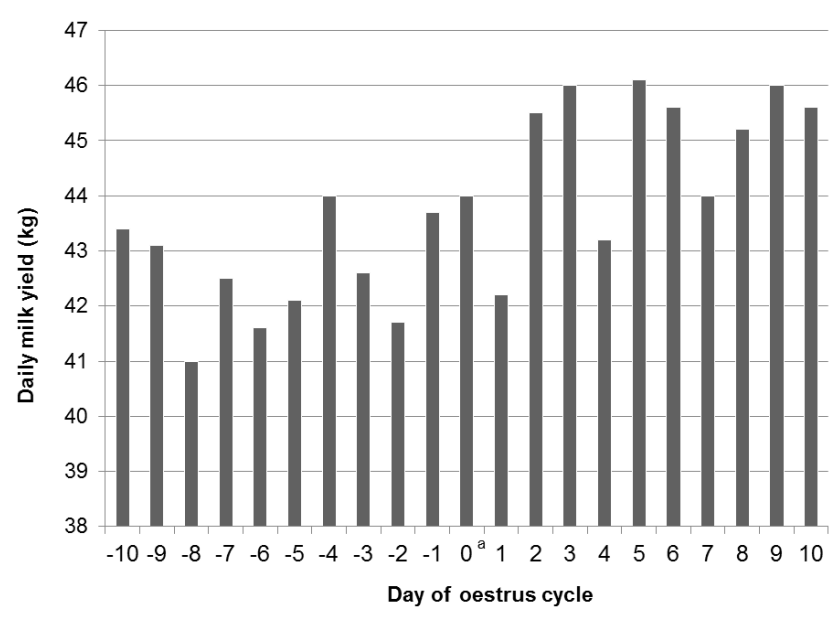

Figure 1. Means of daily milk yield $(\mathrm{kg})$ during the oestrus cycle $(n=525$ days $){ }^{\text {a }}$ Day of oestrus.

\section{Discussion}

In the current study an average daily fresh matter intake of $42.5 \mathrm{~kg}$ (19.8 kg dry matter) per cow and day was analysed. Ulbrich et al. (2004) described a dry matter intake of $23.5 \mathrm{~kg}$ as necessary for cows of a body weight of $650 \mathrm{~kg}$ producing $40 \mathrm{~kg}$ of milk per day with a fat and protein content of 4.0 and $3.4 \%$, respectively. Schwarz (2008) described a range of 14 to $24 \mathrm{~kg}$ dry matter intake per day as required for saturation and normally working digestive processes in dairy cows. On average, cows used for this study produced $41.6 \mathrm{~kg}$ of milk per day, containing $4.0 \%$ fat and $3.3 \%$ protein. Hence, determined dry matter intake lies within the regular limits.

It has been previously reported that cattle fed in a barn have an average number of 12.1 meals per day (Vasilatos and Wangsness, 1980), or, according to Dado and Allen (1994), around 11 feeding periods per day. Also, an average total feeding time of $253.6 \mathrm{~min}^{-1}$ (Vasilatos and Wangsness, 1980) or $301.0 \mathrm{~min}^{-1}$ (Dado and Allen, 1994) was reported for cows held in a barn and fed ad libitum. In this study the individual visits to the feeding trough and the total time spent feeding were recorded automatically by the RIC sys- 
tem. It was shown that cows visited the trough more often ( $\bar{x} 48.5$ visits per day) and spent less time feeding per day $\left(\bar{x} 190.8\right.$ min $\left.^{-1}\right)$ compared to Vasilatos and Wangsness (1980) and Dado and Allen (1994). In the current study the amount of fresh matter cows consumed per visit to the trough varied widely. Therefore, the number of visits to the trough per day cannot directly be compared with the number of meals or feeding periods per day as investigated in the studies mentioned above. Nevertheless, Kaufmann et al. (2007) also used electronic weighing troughs to record the same parameters for a total number of 70 lactating dairy cows. The investigations were performed under similar conditions. With average values of 32.07 visits to the feeding trough, $201.42 \mathrm{~min}$ spent feeding and $21.58 \mathrm{~kg}$ dry matter intake per day, the results come close to the results found in the current study. Using the same RIC system as used for the investigations shown in the present study, Proudfoot et al. (2009) found the highest average feeding time in primiparous cows for the week before calving under competitive feeding treatments ( $2: 1$ (cows : feed bin)) $\left(216 \mathrm{~min}^{-1}\right)$. Average values higher than $250 \mathrm{~min}^{-1}$, as described by Vasilatos and Wangsness (1980) and Dado and Allen (1994), were not reached. Furthermore, the lowest average number of visits to the feeding trough found by Proudfoot et al. (2009) was 23, and was recorded for multiparous cows 1 week after calving under noncompetitive feeding treatments (1: 1 (cows : feed bin)). It has already been proven that competitive feeding situations such as a reduced feeding space per cow at the feed bunk (Huzzey et al., 2006) or a cow : feed bin ratio of $2: 1$ instead of $1: 1$ (Proudfoot et al., 2009; Harb et al., 1985) can have a reducing effect on the time spent feeding per day (min). Considering the fact that cows were housed in tie-stall barns and were fed ad libitum, the feeding situations were noncompetitive in both of the studies of Vasilatos and Wangsness (1980) and Dado and Allen (1994). The high average values recorded for the parameter "time spent feeding per day (min)" in those two studies could therefore be explained by the fact that no displacements at the feeding trough occurred, which otherwise would have interrupted the feeding period and thus reduced the total time spent feeding per day.

The effect of the day of oestrus was significant for two of the investigated parameters ("daily feed intake amount (kg)" and "time spent feeding per day (min)"). Oestrus had a reducing effect on both parameters (10.3 and $20.8 \%$, respectively). In the study of Reith and Hoy (2012), rumination time was related to oestrus in dairy cows. They determined rumination time to be significantly reduced on the day of oestrus by $17.0 \%\left(74 \mathrm{~min}^{-1}\right)$ when compared to the reference period ( 3 days before and 3 days after oestrus). This effect of oestrus can be directly related to the significantly reduced feed intake amount on the day of oestrus found in the current study. A reduced feeding time on the day of oestrus was observed earlier in 20 Friesian cows held in a straw yard by Phillips and Schofield (1990). They recorded an increase in feeding time on the day before oestrus and a decrease on the day of oestrus and the day after oestrus when compared to all remaining days of the oestrus cycle. However, this behaviour was not observed in this study for the 20 Friesian cows held in cubicles. The "daily number of visits to the feeding trough" was also reduced by $9.1 \%$ on the day of oestrus when compared to the reference period. However, this difference was not significant. The drop in the values on the day of oestrus obviously is caused by the higher physical activity which appears in cows during oestrus (Hurnik et al., 1975; Kiddy, 1977; Lewis and Newman, 1984; Schofield et al., 1991). Arney et al. (1994) observed physical activity in dairy cows to gradually increase from 3 days before oestrus and to exponentially decline after peaking on the day of oestrus. Hurnik et al. (1975) found cows to spend more time walking and less time resting and eating when in oestrus than when not in oestrus.

"Daily milk yield (kg)" was not affected by oestrus but was characterized by high variation among all days of the oestrus cycle. In consideration of earlier studies, where milk yield was observed to be reduced at the first milking after onset of oestrus, followed by a rebound enhancement at the second milking (Horrell et al., 1985), significantly reduced on the day of oestrus (Schofield et al., 1991), or declined slightly from 1 day before oestrus until 2 days after oestrus (Lewis and Newman, 1984), a decline in milk yield on the days around oestrus could have been expected. In the current study, milk yield was slightly reduced 1 day after oestrus by $1.8 \mathrm{~kg}(4.1 \%)$, followed by an increase of $3.3 \mathrm{~kg}(7.8 \%)$ on day 2 after oestrus. Hence, results come close to the results found by Horrell et al. (1985).

Parity was investigated for its effects on all parameters except daily milk yield $(\mathrm{kg})$. It had a significant effect on all three parameters. When compared to cows of higher lactations, cows of first lactation were characterized by a lower feed intake amount of $14.4 \%$ but a higher number of visits to the feeding trough $(18.0 \%)$ and a longer time spent at the feeding trough per day $(14.1 \%)$. Similar results were found by Proudfoot et al. (2009), who also used the RIC system to investigate the effect of competition (2:1 (cows : feed bin)) on the behaviour and feed intake of 110 Holstein dairy cows. They found a lower dry matter intake $(\mathrm{kg})$, a higher number of visits and a longer time spent at the feeding trough per day for primiparous cows. Dado and Allen (1994) also found more feeding times per day with a lower dry matter intake in primiparous cows compared to multiparous cows. However, they observed multiparous cows to show a longer total time spent feeding per day than primiparous cows (260 vs. $213 \mathrm{~min}^{-1}$ ). Maekawa et al. (2002) also found longer feeding periods ( $47 \mathrm{~min}^{-1}$ ) in multiparous cows when compared to primiparous cows. However, according to Ulbrich et al. (2004), older cows have a higher velocity of feed intake when compared to heifers. Furthermore, in the study of Firk et al. (2002) it was found that activity, measured by pedometers, decreased significantly with increasing number of parity. The higher activity in primiparous cows might be directly 
related to the higher number of visits to the feeding trough observed in the current study. The statement of Ulbrich et al. (2004) and the findings of Firk et al. (2002) might explain the observed result of a higher feed intake amount in older cows, accompanied by fewer visits to the feeding trough and less time spent feeding per day.

The reducing effect of oestrus was more highly pronounced in multiparous cows than in primiparous cows in all three parameters. Nevertheless, Reith and Hoy (2012) found the decrease in rumination time to be more pronounced in primiparous cows than in older cows.

In conclusion, the results indicate that feed intake behaviour is influenced by oestrus. However, the condition for accurate monitoring of the required parameters is the installation of an RIC system. This prerequisite makes it difficult to use monitoring of feed intake behaviour as an auxiliary heat detection method to improve fertility management.

Edited by: A.-E. Freifrau von Tiele-Winckler

Reviewed by: two anonymous referees

\section{References}

Arney, D. R., Kitwood, S. E., and Phillips, C. J. C.: The increase in activity during oestrus in dairy cows, Appl. Anim. Behav. Sci., 40, 211-218, 1994.

Bostedt, H.: Factors influencing fertility, in: Fertility management in Cattle, 5th ed., Frankfurt am Main, Germany, 313-315, 2006 (in German).

Dado, R. G. and Allen, M. S.: Variation in and Relationships Among Feeding, Chewing, and Drinking Variables for Lactating Dairy Cows, J. Dairy Sci., 77, 132-144, 1994.

Firk, R., Stamer, E., Junge, W., and Krieter, J.: Systematic effects on activity, milk yield, milk flow rate and electrical conductivity, Arch. Tierz., 45, 213-222, 2002.

Gwazdauskas, F. C., Lineweaver, J. A., and McGilliard, M. L.: Environmental and Management Factors Affecting Estrous Activity in Dairy Cattle, J. Dairy Sci., 66, 1510-1514, 1983.

Harb, M. Y., Reynolds, V. S., and Campling, R. C.: Eating behaviour, social dominance and voluntary intake of silage in group-fed milking cattle, Grass Forage Sci., 40, 113-118, 1985.

Horrell, R. I., Macmillan, K. L., Kilgour, R., and Bremner, K.: Changes in milk yield and composition at oestrus in dairy cows, J. Dairy Res., 52, 9-16, 1985.
Hurnik, J. F., King, G. J., and Robertson, H. A.: Estrous and related behaviour in postpartum Holstein cows, Appl. Anim. Ethol., 2, 55-68, 1975.

Huzzey, J. M., DeVries, T. J., Valois, P., and von Keyserlingk, M. A. G.: Stocking Density and Feed Barrier Design Affect the Feeding and Social Behavior of Dairy Cattle, J. Dairy Sci., 89, 126-133, 2006.

Kaufmann, O., Azizi, O., and Hasselmann, L.: Feeding behaviour of high yielding dairy cows during early lactation, Züchtungskunde, 79, 219-230, 2007 (in German).

Kiddy, C. A.: Variation in Physical Activity as an Indication of Estrus in Dairy Cows, J. Dairy Sci., 60, 235-243, 1977.

Lewis, G. S. and Newman, S. K.: Changes Throughout Estrous Cycles of Variables That Might Indicate Estrus in Dairy Cows, J. Dairy Sci., 67, 146-152, 1984.

Lopez, H., Sattler, L. D., and Wiltbank, M. C.: Relationship between level of milk production and estrous behavior of lactating dairy cows, Anim. Reprod. Sci., 81, 209-223, 2004.

Maekawa, M., Beauchemin, K. A., and Christensen, D. A.: Chewing Activity, Saliva Production, and Ruminal $\mathrm{pH}$ of Primiparous and Multiparous Lactating Dairy Cows, J. Dairy Sci., 85, 11761182, 2002.

Phillips, C. J. C. and Schofield, S. A.: The effect of environment and stage of the oestrous cycle on the behaviour of dairy cows, Appl. Anim. Behav. Sci., 27, 21-31, 1990.

Proudfoot, K. L., Veira, D. M., Weary, D. M., and von Keyserlingk, M. A. G.: Competition at the feed bunk changes the feeding, standing, and social behavior of transition dairy cows, J. Dairy. Sci., 92, 3116-3123, 2009.

Reith, S. and Hoy, S.: Relationship between daily rumination time and estrus of dairy cows, J. Dairy Sci., 95, 6416-6420, 2012.

Schofield, S. A., Phillips, C. J. C., and Owens, A. R.: Variation in the milk production, activity rate and electrical impedance of cervical mucus over the oestrous period of dairy cows, Anim. Reprod. Sci., 24, 231-248, 1991.

Schwarz, F. J.: Concentration and intake amount of nutrients in lactating dairy cows/Feed intake, edited by: Kirchgessner, M., in: Animal nutrition: Guide to the study, advice and practice, 12th ed., Frankfurt am Main, Germany, 366-372, 2008 (in German).

Ulbrich, M., Hoffman, M., and Drochner, W.: Feeding regime, performance motivation and animal health/Presentation of feed, in: Feeding and animal health, Verlag Eugen Ulmer, Stuttgart, Germany, 59-64, 2004 (in German).

Vasilatos, R. and Wangsness, P. J.: Feeding Behaviour of Lactating Dairy Cows as Measured by Time-Lapse Photography, J. Dairy Sci., 63, 412-416, 1980. 